\title{
Perspectives on ecological approaches in Australian archaeology
}

\author{
Peter Veth', Susan O'Connor' and Lynley A. Wallis²
}

In this postmodern World the evocation of ecological approaches in archaeology conjures up visions of banal environmental determinism and passive human actors receiving their cues from terrifying landscapes. And yet anything but the most superficial critique of the myriad approaches that have been labelled ecology easily illustrates that social and cognitive factors may be given voice at both the individual and group level. As Pardoe (1994:182) has argued in a recent review of studies of human ecology in Australia "Humans are one species capable of rewriting deterministic ecological equations through consciousness and intentionality".

Whitley (1998:3) notes that the traditional processual approach sees cultures as "...systems of socially transmitted behaviour patterns that relate communities to their ecological settings. Culture change is...a process of adaptation to the environment and natural selection". A range of frameworks has now been presented in Australian archaeology (e.g. Head 1986, 1994), however, to facilitate some recognition of the convergence inherent between explanatory approaches which give primacy to social relations (e.g. Friedman 1979) and those focusing on biophysical factors (Wenke 1981; Winterhalder and Smith 1981). It is argued that such frameworks aim to accommodate both social and ecological/evolutionary approaches. The somewhat artificial historical dichotomy has also been liberated by systems approaches that engender multicausal explanations in a move away from any simplistic prime mover (cf. Hutchet 1991).

Many studies in Australian archaeology have employed ecological explanatory frameworks, however, there is little consensus between different reviewers about which particular researchers have been exponents of the approach. This is undoubtedly a product of how these reviewers have chosen to characterise ecological explanatory paradigms. For example, Lourandos and Ross $(1994: 55,56)$ note that "The 'Intensification Debate' in Australia was largely a reaction to the traditional paradigms which viewed Australian Aborigines as essentially static and under environmental control". Hutchet (1991:48) argues that while cultural ecology has assumed greater importance over the last two decades (e.g. Smith 1986; Veth 1989) its explicit use still remains low in his study of the history of theories in Australian archaeology. However, in his comments on Australian workers who have adopted evolutionary theory into archaeology Pardoe (1994:187) notes:

The synthesis of studies of humanity, past and present, is taking place through the incorporation of evolutionary ecology. This has been the explicit focus of my modelling of biological, territorial and social organisation of River Murray peoples (Pardoe 1988a, 1990). The utility of evolution and ecology as archaeological theory which relates land, people and society is evident in the increasing

1 School of Anthropology and Archaeology, James Cook University, Townsville, QLD 4811, Australia

2 Department of Archaeology and Natural History, RSPAS, The Australian National University, Canberra, ACT 0200, Australia number of people setting out models of human ecology (e.g. Frankel 1991; M.A. Smith 1989; O'Connor et al. 1993).

In this paper we will explore the plurality of understandings that are evident from a range of studies informed by ecological perspectives in Australian archaeology. We have deliberately divided the discussion into three parts focusing on representative studies through time from two major geographic zones (the arid zone and the coast/islands) followed by a consideration of the history of reconstructive methods and techniques, such as palynology. In doing so we hope to illustrate that:

1. ecological approaches have been used in Australian archaeology for over 40 years (e.g. Birdsell 1957);

2. ecology may incorporate a wide range of approaches, from mono- to multi-causal, from deterministic to recursive, from static to evolutionary and that this variation is largely a product of refinements through time and spatio-temporal scales of analysis;

3. ecologically-oriented inquiries have been the powerhouse for many of the seminal models which have sought to explain the dynamics of culture change (or stasis) in Aboriginal Australia; and

4. ecological models do not per se exclude considerations of social relations. In fact it will be argued that ecology can actually marry social and evolutionary perspectives, often in a convincing fashion.

With reference to this last point one view has it that: The link between evolutionary models of human behaviour and social organisation is through ecology. Landscape is the stage upon which life's themes of energy and reproduction are played out. It is the unique combinations of ecology, evolution and society which produce historical sequences of change and variation (Pardoe 1994:189).

\section{Case studies from the arid zone}

Richard Gould has been proposing ecologically oriented models for the Western and central Australian deserts for over 30 years. Changes in the way he attempts to explain the scale and dynamics of behavioural responses to the challenges of aridity are evident through time (e.g. Gould 1967, 1968, 1969, 1971, 1973, 1974a, 1974b, 1977a, 1977b, 1978a, 1978b, 1980, $1982,1991,1996$ ). An example of two works that specifically focus on issues of adaptation (Gould 1977, 1991) will serve to illustrate this point.

In what might be termed a conservative model Gould (1977a) elaborated on the essential characteristics of the Australian Desert Culture; one he argued was stable and uniform demonstrating long-term continuities in group composition, lithic technology and extractive strategies. His attitude to ecological limiting factors is clear when he (Gould 1977a:182) concludes:

From a deterministic viewpoint, the core desert can be seen as a great leveler of human behavior in the sense that it limits the optional responses by anyone with a hunting-and-gathering mode of subsistence who tries to live there. In fact, there 
appear to be no options except the unique kind of risk-minimising opportunism described earlier for the present day Western Desert aborigines, and anyone attempting to follow a seasonal round or adapt in any other way would undoubtedly perish.

In a later paper on strategy switching by groups in response to drought Gould (1991:25) has shifted ground and argues that "There is no reason to assume that a particular group of arid land foragers must adhere to a single set of expectations...". While some groups might regularly switch from drought escape (where entire areas are temporally abandoned) to drought evasion (where family groups retreat into dependable 'home' country) others may employ a configuration which is dominantly in one mode or the other. As Gould (1991:30) concedes:

Since arid Australia is not a uniform or homogeneous area, it is reasonable to expect and to try to model different regional outcomes according to local variations in biogeography.

Hayden's (1976) initial work in the Western Desert examined the nature of assemblage variability by testing the assumptions and expectations of two different models (functional versus multi-dimensional); essentially contrasting cultural versus economic explanations. Hayden (1976:459) concluded that 'culture' was the dominant influence and that "Western Desert assemblages appear to be surprisingly homogeneous within broad ethnic boundaries". The economic or multi-dimensional model that he eschewed gives particular attention to issues of mobility, multi-functionality and resource distribution (1976:88-91) in ways that are informed by ecological approaches. It is surprising and pertinent, therefore, when he (Hayden 1976:91) actually acknowledges that the multi-dimensional model essentially subsumes his preferred functional model.

In contrast to the expectations of the 'culture' model, O'Connell (1977) noted significant differences in the composition of stone tool assemblages studied from central Australia, which he attributed largely to their varying function. He focused on the relationships between sites and the structure of lithic and biotic resources, concluding that proportional variations in seed grinding implements and the composition of flaked stone tool assemblages were dependent on the nature of nearby seed stands and relative access to quarry sources (O'Connell 1977:280). Further studies using human ecology and adaptive approaches by O'Connell and his colleagues included optimal foraging theory to explain strategies of plant use by the Alyawarra (O'Connell and Hawkes 1981) and an examination of the 'broad spectrum' seed-based revolution within the arid zone of Australia (Edwards and O'Connell 1995).

Employing somewhat similar techniques to O'Connell, Cane (1984:13) set out to "make direct interpretations of prehistoric debris" and land use pattems from open sites in the Great Sandy Desert through artefact-oriented ethnography and assemblage analysis. His ecological framework is clear when he (Cane 1984:14) notes "Leading from this detailed economic picture it is hoped to assess the correlation between biological resources, economic behaviour and the archaeological deposits found at sites". He makes an extended case for real variation between assemblages, arguing sites that were alike environmentally and economically contained more or less the same kind of archaeological debris (Cane 1984:262). In what is essentially a conflation of behavioural and ecological considerations Cane believes that on the basis of surface assemblages it is possible to accurately ascertain the relative contribution of seeds, the manufacture of maintenance items, patterns of movement and foraging behaviour and even the seasonality of site occupation. Cane (1984:271) concludes that the considerable variation between habitation sites related "to the environmental and economic characteristics of different sites rather than stylistic, cultural and ethnic differences".

While essentially concurring with Gould that Aboriginal people of the Great Sandy Desert had experienced a "stable hunting and foraging way of life" for thousands of years (Cane 1984:282-3), he drew attention to the lack of evidence for the uniformity between peoples occupying core deserts (cf. Gould 1971:174). For example, groups in the Sandy Desert enjoyed greater economic diversity and a noticeable degree of seasonality in their settlement/subsistence rounds in comparison to the Ngatatjara of the Gibson Desert.

In response to O'Connell and Hawkes' (1981) research with the Alyawarra, Pate (1986:95) employed optimal foraging theory to analyse Gould's ethnographic data regarding plant use among the Ngatatjara. He argued that "the corrrespondence of Ngatatjara dietary breadth changes to optimal foraging predictions" could be "explained as an adaptive response to the unpredictable Western Desert rainfall. By minimising the time allocated to food procurement, energyefficient foraging reduced the risk involved in the exploitation of scattered, ephemeral water sources". Thus Ngatatjara plant food use patterns were seen to provide additional support for a risk-minimising hunter-gatherer adaptive strategy in this marginal Gibson Desert habitat.

Following on from previous suggestions by a number of workers who had considered long-term human responses to cycles of heightened aridity (e.g. Horton 1981; Hughes and Lampert 1980), Brown (1987) developed a scenario for the occupation of the Hamersley Ranges during and after the Last Glacial Maximum (LGM). He specifically argued that following climatic amelioration after about 15,000 BP groups may have resettled previously abandoned areas and have permanently colonised very low rainfall areas for the first time (1987:1). The Hamersley Ranges were seen as a haven during the LGM, with Brown (1987:41) noting that there was "...no noticeable hiatus in the depositional history in any of the shelters" and additionally that there was evidence for "...a trend towards increased usage of marginal environments in the Holocene" (1987:46). Brown clearly sees regional occupation patterns being strongly determined by water availability and drainage configuration, concluding that while groups made a Pleistocene adaptation to the Hamersley Ranges, the evidence for more systematic use of more marginal fringing ranges and lowlands was essentially restricted to the Holocene (1987:51, 52).

Hiscock's (1988) study of settlement patterns and artefact manufacture at Lawn Hill possibly represents one of the most successful attempts at integrating ecological perspectives with behavioural studies. Also addressing the theme of human responses to cycles of aridity, Hiscock (1988:i) explicitly set out to examine "...the ways in which technology and settlement responded to changes in environmental conditions". His review of arid Australia concluded that abandonment at the LGM was widespread and that where 'refuges' were occupied rationing was evident and that spatial variations in technology were very high due to this rationing behaviour.

At the Colless Creek Cave site usage intensified during the LGM as evidenced by increase in discard rates, fire frequency, degree of trampling and processing of fauna (Hiscock 1988: 219). People responded to an overall decrease and reliability 
of resources by restricting their territory. This led Hiscock to support a hypothesis for economic re-organisation to cope with environmental stress (1988:228). He focuses on riskminimisation strategies when he (1988:246) notes:

Despite this adjustment people were no longer able to exploit some portions of the landscape as they had previously, perhaps because the increased aridity brought with it greater risk and/or fewer returns in those areas. One response to these new circumstances was an avoidance of those risky environments and a consequent restriction of territory.

In his research program in central Australia Smith (1988, $1989,1996)$ has considered the behavioural responses of groups to arid cycles through the LGM and also to more subtle climatic oscillations in the Holocene. He sees shifts in residential mobility patterns and also in territoriality as providing the appropriate mechanism for groups to persist in the central Australian Ranges during the LGM and also to possibly maintain some connection with the arid lands to the west. Smith (1996:66) notes:

...conditions during the last glacial maximum would have had a number of consequences for human groups...the thinning out of watering points would have left many parts of the arid zone inaccessible...groups would have been largely restricted to the major montane and piedmont regions or major riverine tracts - areas with the highest density of watering points. The desert lowlands...most likely would have been abandoned...

It is clear that the Pleistocene-aged assemblages from the key site of Puritjarra are different to those of the Holocene, however, when it is noted that between Layers II and la the rate of artefact discard increases by a multiple of 700 (Smith 1988: Table 4.4), that there is a 10 fold increase in the rate of retouch (Smith 1988:Table 4.13) and that a 95\% decrease occurs in the average weight of cores and artefacts (Smith 1988: Tables 4.8, 4.10). These significant changes suggest that a different kind of land-use pattern was in place during the Pleistocene. By the mid- to late Holocene human responses to environmental change are seen in the emergence of intensive seed grinding behaviour, which is linked to a minor arid phase and population growth, and then a major efflorescence in occupation over the last thousand years which is essentially driven by population increase and partitioning of territory (cf. Smith 1996:68). This late phase of intensification is not explicitly linked to any ecological parameters per se.

The first colonisation model specifically for the Australian arid zone was proposed by Veth $(1989,1993 a)$ explicitly adopting a biogeographical approach. The model aimed to explain the timing for human occupation in different parts of the arid zone and to examine the reasons for demographic changes through time. The model systematically challenged Gould's (1977a) 'conservative desert culture' and predicted that occupation of the arid zone from the late Pleistocene was likely to have been a highly dynamic process, marked by significant changes in human economy, technology and demongraphy. One of the core issues identified in the model was the degree to which late Pleistocene people had fully developed arid zone adaptations to occupy truly arid landscapes through space and time.

The majority of archaeological evidence supports the contention that in response to the hyper-aridity of the LGM groups restructured their foraging and residential ranges leading to clear changes in occupational sequences at a range of sites (cf. O'Connor et al. 1999). Another core issue, that some parts of the arid zone may have been uninhabited until the mid-Holocene, is now rejected as new Pleistocene-aged sequences become available from the desert lowlands (O'Connor et al. 1999; Veth in press). Increasingly it appears that generally better watered landscapes were populated earlier, with the first significant permanent occupations of arid landscapes occurring around the edge of the arid core during and after the LGM.

The theme that peoples' adaptation to truly arid conditions only occurred through time is taken up by Ross et al. (1992:108) who argue that "Behavioural responses to aridity developed slowly as arid conditions enveloped most of the Australian continent in the late Pleistocene" and that by the height of the LGM "...the occupants' adaptive response to the harsh environment of the time was shown in the distribution of sites around the better watered refugia of the arid zone" (Ross et al. 1992:109).

They develop an extended argument in which environmental conditions set strong boundary conditions beyond which behaviour cannot vary, however, within which social and technological forces become dominant through time. A three phase model is suggested for the peopling of the arid zone, the first of which sees widespread occupation occurring in areas which became increasing arid (Ross et al. 1992:77). At this stage the effects of environment are dominant. The second phase sees the first adaptations to truly arid landscapes with some human impact on ecology. The final phase gives prominence to social options over environmental constraints giving rise to the desert efflorescence of the last couple of thousand years. The argument that environmental change in the Holocene acted as a trigger to cultural change is rejected when they (Ross et al. 1992:107) note:

It is clear...that the timing and magnitude of Holocene environmental change in the arid zone is not in phase with the timing and magnitude of change seen in the archaeological record from the late Holocene.

Lourandos (1997) takes a similar and increasingly common view (e.g. Smith 1996; Veth 1995, 1999) whereby ecological considerations are key considerations for Pleistocene patterns of occupation with social mechanisms for change becoming dominant by the Holocene and certainly for the late Holocene. Lourandos (1997:175) argues that evidence for ephemeral occupation patterns in the arid zone during the Pleistocene and for abandonment of some sites and sub-regions lends support to Hiscock's contention $(1988,1994)$ that, while people occupied large areas of the arid zone during favourable conditions, they were not adjusted to life in fully arid conditions.

Themes of arid zone ecology are brought to the coast by Morse (1993a) when she considers the implications of maritime economies operating within an arid zone hinterland in northwest Australia (see also O'Connor and Veth 1993; Veth 1993b, 1995). Morse concluded that Aboriginal groups followed and adapted to the changing Pleistocene shoreline of her northwest study area during the LGM. She also acknowledges that groups may well have fallen back on the Pleistocene coastline from the arid interior (Morse 1993a:15).

Morse discusses other studies that showed that Pleistocene shorelines may have been utilised by hunter-gatherers during the LGM. She cites Close and Wendorf (Morse 1993a:282) who argued that hyper-aridity would have rendered most of 
north Africa uninhabitable 18,000 years ago, with only a small number of exceptions including the Mediterranean and Atlantic coasts of Maghreb. Morse (1993a:283) additionally notes that increased aridity in central and western Morocco may have forced groups to take refuge on the sea. Finally, she cites work by Bar-Yosef for trade of marine shells up to $300 \mathrm{~km}$ inland in the Mediterranean Levant, clearly demonstrating contact with the coast during the LGM.

Three further studies on the arid northwest coast on the Montebello Islands (Manne 1999; Pulsford 1994; Veth 1993b, 1995), now located $100 \mathrm{~km}$ offshore, have sought to characterise the nature of desert coastal economies of Australia during the terminal Pleistocene and early Holocene. The Noala Cave site covers the period from approximately $30,000 \mathrm{BP}$ to the early Holocene. Detailed analysis of the economic fauna from Noala Cave illustrates a strong reliance on small-sized terrestrial mammals, in additional to medium-sized varanids, lizards and snakes (Manne 1999:106). The evidence for marine resources only becomes appreciable between approximately $12,000 \mathrm{BP}$ and $10,000 \mathrm{BP}$, probably as a function of the relative proximity of the transgressing shoreline to the cave. After this time the adjacent Haynes Cave site provides evidence for more intensive occupation.

The Haynes Cave site, which dates from the early Holocene, demonstrates the opportunistic exploitation of a wide variety of desert sand plains mammals in addition to increasing reliance on the marine resources of an emerging rich littoral environment comprising fringing reef, mangroves and rocky shores. Marine resources may well have had increased importance towards the end of the Dry season (Pulsford 1994:114).

The dominant theme to emerge from a number of these studies (Manne 1999; Morse 1993a; O'Connor and Veth 1996; Pulsford 1994; Veth 1993b, 1995) is the flexibility of arid zone hunter-gatherers in combining localised patterns of coastal foraging with high residential mobility and large foraging ranges in the arid interior.

This theme is also developed by Moya Smith (1993) in her study of the semi-arid zone of southwestern Australia. She adopted a framework developed by Ambrose and Lorenz (1990) in an attempt to predict the likely behaviours and archaeological correlates of a landscape characterised by an unpredictable and scarce resource structure (see also O'Connor et al. 1993 for a similar treatment of the northwest). Smith (1993: 357) concluded for both the arid coast and interior that residential mobility was very high, group size and population density were low with high dietary breadth. With reference to the resource structure model, the assemblages demonstrated high stylistic uniformity, minimal spatial organisation within sites, a low intensity of occupation at habitation base camps, the predominant use of local raw materials with ethnographic support for the exploitation of a broad suite of mainly plant species.

Recently the important rockshelter site of Serpent's Glen has been dated to greater than $23,500 \mathrm{BP}$, representing the first site of clearly Pleistocene age within the Western Desert (O'Connor et al. 1998). This site is firmly located within the Western Desert and cannot be argued to represent an outlier of a major range system, as has the site of Puritjarra by its excavator (Smith 1989). The sequence may be divided into three units; a Pleistocene unit with a very low density of flaked stone, charcoal, ochre, bone and eggshell, a middle unit which is culturally sterile and an upper unit which dates from approximately $4700 \mathrm{BP}$ to the present. The upper unit contains all categories of cultural material in far greater quantities than the lower unit with
$98 \%$ of all artefacts coming from this unit (O'Connor et al. 1998:16, 17).

Importantly, the middle unit is seen to represent a cultural hiatus where sedimentation has occurred without occupation, and not a stratigraphic unconformity and hiatus ( $O^{\prime}$ Connor et al. 1998:17, 18). The authors argue that while a hiatus in one site may not reflect regional trends, its presence at an increasing number of sites is consistent with models which argue for demographic shifts during the LGM (cf. Veth 1995).

A concurrent study of indices of bone fragmentation at Serpent's Glen returned higher values than that recorded for Puntutjarpa (Gould 1996) emphasising the protein-depauperate nature of the surrounding desert lowlands. In reconciling behavioural responses to environmental cycles the authors (O'Connor et al. 1998:21) conclude:

...the apparently ephemeral nature of the Pleistocene assemblages at Serpent's Glen and the presence of a clear cultural hiatus highlight the degree to which groups employed highly flexible settlement strategies to cope with resource stress at different scales of time (cf. Gould 1991).

The theme of risk-minimisation is developed at length by Thorley (1998a, 1998b) who combined the principles of regional landscape formation with ecological approaches to the analysis of human settlement in the Palmer River catchment of the central Australian ranges. The excavation of Kulpi Mara dates back to 30,000 BP when the climate was cool and wet. With increasing aridity from $23,000 \mathrm{BP}$ he argues the site is abandoned until approximately 13,000 BP from when there is minimal occupation until the mid-Holocene. Further, his review of Puritjarra led him to conclude that there was negligible evidence for continuous occupation through the LGM (Thorley 1998a:319-24). Unlike Smith (1993), he argued for a relatively late adaptation to aridity in the form of settlement and technological strategies for coping with risk (Thorley 1998:343). He (Thorley 1998a:ii) notes that:

...by using the combined data from over 20 excavated sites in central Australia, it was concluded that the mid-to late Holocene provided the first evidence for the development of strategies well-suited to the risks imposed by a widely fluctuating arid environment. Among these were the use of low-risk seed foods and the positioning of aggregation sites to take advantage of rich though temporary resources near ephemeral waters.

\section{Ecological approaches to the archaeology of coasts and islands}

Australian coastal and island archaeology has a record confined mostly to the mid-late Holocene (see Barker 1991; Kendrick and Morse 1982; Morse 1993a, 1993b; O'Connor 1999; Veth 1993 for some exceptions). As alluded to earlier, archaeologists have been more comfortable accepting the dramatic changes in climate and sea level reflected in the long time span of human Pleistocene occupation as having "played a dominant role in explanations of the processes of human colonisation and adaptation" (Rowland 1999:12). These broad scale changes of large amplitude appear to correlate with broad scale changes in the archaeological record such as the abandonment of sites, and by inference entire geographic regions, by populations, although the correlation may be at least partly a product of scale, both spatial and chronological (at two standard deviations we are usually dealing with several thousand years and sample sizes are small over vast geographic 
areas). In contrast, social/economic models have held sway as primary explanations for change in the archaeological record in the mid-to late Holocene, as climatic/environmental oscillations have been perceived as too insignificant, or too poor a fit chronologically, to have had marked impacts on human behaviour. Because of this, coastal/island studies have reflected the schism between ecological/environmental and internalised approaches to explaining cultural change more starkly than the archaeology of other regions.

Rowland $(1983,1999)$, one of the chief advocates of the 'environmental position', has recently sought to clarify his views to his critics. In this context he has revisited many of the issues which highlight the polarity in the environmental versus internalist debate and has undertaken a more detailed and incisive analysis of the historical development of these positions than space will permit here. We commend the reader to his excellent review (Rowland 1999). Most importantly, he argues that the internalists have tended "to underestimate the extent and significance of Holocene environmental change" and to misrepresent the environmental/ecological position (1999:11).

Despite accusations to the contrary (e.g. Thomas 1981:165), the environmental/ecological approaches adopted by most Australian coastal archaeologists have not been deterministic, but rather have acknowledged that people cannot live outside their environment. Such approaches therefore attempt to examine the interaction of cultural and environmental processes.

Bowdler's (1979) interpretation of the archaeological record of the northwest coast of Tasmania and 'why the Tasmanians stopped eating fish' exemplifies this type of integration of 'ecological' and what she calls 'economic' interpretation. Bowdler (1979:424) argues that "between c. 18,000 B.P. and c. 8000 B.P. a coastal adaptation was made to a low energy littoral and a fairly open coastal strip. This adaptation depended on having a certain amount of ecological space within which activities could be seasonally or otherwise diversified". The fauna in the lower levels of Rocky Cape reflects this adaptation. Around 5500 years ago there was in her view "a two-pronged ecological squeeze" (Bowdler 1979:424). In summary, 1) as sea level rose, the coastal strip became narrower and the islands were formed, and 2) the rainforest encroached to the coast, "possibly isolating stretches of coastline" (Bowdler 1979:424). Thus a new adaptation had to be made to a restricted area of high energy coastline and an 'economic' decision was made to drop fish from the diet and concentrate time and energy on higher yielding resources such as seal and abalone. It was only within the last 3000 years that there is evidence for people manipulating this new environment with fire. "Once that was accomplished a larger ecological space was again established. Economic strategies were again diversified, but fish were not reincorporated into the diet" (Bowdler 1979:425).

Similarly, Hiscock (1999) has recently reinterpreted changes in the dominance of shellfish species in the midden levels of the western Arnhem Land shelter sites in terms of ecological change in mangrove communities. These sites show a shift from Geloina and Telescopium to Cerithidae. Schrire (1982) also interpreted this pattern as resulting from ecological change, but believed it reflected the result of the introduction of buffalo on the ecology. Hiscock brings a multitiered approach to the archaeology, geomorphological palynology and chronology that shows that the shift probably reflects one from Rhizophora dominated forest to Bruguiera and Avicennia forest as a response to increasing salinity. In his view the changing distribution of shellfish species simply mirrors the changing availability of these animals within the closest mangrove environment (Hiscock 1999:96). However, Hiscock's model is not a simple one as it goes on to show how this environmental change had consequences beyond the alteration in diet. In short, the ecological changes on the coastal zone and the flood plains resulted in changes in resource distribution and abundance which provided new opportunities for ecological diversification and settlement, which in turn had ramifications for social and technological change. For example, Hiscock (1999:98) suggests that "dating and temporal variation in points reveals a pattern that closely parallels environmental change in the region". While he sees environmental changes as catalysts for economic and technological reorganisation, the behavioural strategies that followed the environmental changes do not follow automatically as a consequence of the environmental change.

O'Connor's (1999) and Veth's (1999) argument that environmental changes in the north west of Western Australia are reflected in changes in the midden record is similarly predicated on linking the fauna in the archaeological record to ecological transformation. A number of midden sites between Shark Bay and the Abydos Plain contain the mangrovedwelling gastropod Terebralia sp. in their lowest levels dating from c. $7000 \mathrm{BP}$. At some stage environmental conditions must have been significantly different from today and in most of these areas the mangrove stands that are necessary to support the Terebralia are no longer extant on these stretches of coastline. In the general absence of local geomorphological data it is assumed that the last dates for Terebralia on the sites indicates the demise of the mangrove communities. To that extent the argument is deterministic, i.e. people cannot eat a resource which no longer exists. However, what they choose to do in response to the disappearance of this resource may be driven by any number of choices which will include social and economic imperatives such as those Meehan (1982) has amply illustrated in her classic study of Anbarra shellfishing in the Blyth River region in Amhem Land. Meehan's study again integrates ecological and social approaches in that it documents the way in which a community responds to continuous ecological changes of various magnitude; for example the temporary destruction of beds of the shellfish staple, Tapes hiantina, as a result of monsoon activity causing flooding of the Blyth River estuary and intertidal zone with freshwater. While Meehan's study emphasises the flexibility with which people deal with such ecological change, Rowland (1999:17-18) cites examples which indicate that in some circumstances such resource loss may result in irreversible changes.

While the studies discussed above may be described as broadly 'ecological' in approach, few Australian researchers have made explicit use of ecological theory, and even fewer have attempted to formulate explicit testable predictions based on such theory.

In a world forum, explicit use has been made of population ecology and cultural ecology in archaeological studies of islands. Because of their isolation, boundedness, simpler biotic systems and in most cases the shallow time depth of human settlement, islands have been seen as the ideal arenas or 'laboratories' for the study of the interaction of cultural and ecological processes (Kirch and Hunt 1997; MacArthur and Wilson 1967).

In a general review of the application of island biogeographic theory to archaeology Burney (1997:438-9) 
outlines the chief goals of such endeavours as to record human colonisation and the impact of settlement with the ultimate aim of disentangling natural from anthropogenic causes and effects from the stratigraphy. Although island biogeographers have invested several decades in ecological research on the effects of relative isolation and land area on migration and extinction rates of island biotas (eg. Diamond 1972; MacArthur and Wilson 1967; Simberloff and Wilson 1970) "investigators have been much slower to fully capitalise on the potentially rich opportunities to examine the paleoecological aspects of human island biogeography" (Burney 1997:438). This is no doubt owing to the technical difficulties of attempting to deduce cause and effect from the stratigraphic record with all the problems of temporal, spatial and systemic resolution that accompanies the analysis and interpretation of proxy data (Haberle 1994; Kirch and Ellison 1994).

As Burney (1997) acknowledges, these goals stretch the capacity of proxy data even in oceanic island situations where anthropogenic influences on island ecosystems and naive biota are significant. In continental island situations, such as Australian offshore islands, where only a few thousand years may have elapsed to mark their status as island, such aims are less applicable and probably not achievable. It is largely for this reason that in the Australian context the application of island biogeographic principles to human use of islands have remained at the level of interpretation.

Jones' use of population ecology and island biogeographic theory to interpret changes in the dietary breadth and the material culture repertoire of the Tasmanians is an early and well known example of the use of ecological theory in such interpretation. Bowdler (1979, 1984), Thomas (1981) and Rowland (1999) have reviewed Jones' shifts of position and the internal inconsistencies in his argument.

In his early work Jones viewed the differences between the mainland Australian and Tasmanian assemblages as indicating gradually improving exploitation of an unfamiliar environment (1966:9) and "adaptation to environmental elements reflecting Tasmania's southerly position" (1968:200) in combination with isolation. In his $\mathrm{PhD}$ he states that he can find no "ecological explanation" (1971:619) for the cessation of fishing and interprets it as a cultural prohibition which while "it may have been inconvenient...did not vitally affect their livelihood" (1971: 620). However, in the same section he foreshadows the ideas that were to develop later - that of the effects of isolation on small populations and draws direct parallels between decreasing island size and viability of human populations:

The disappearance of bone tools from the technology and the maintenance on the prohibition on fish eating, may reflect only two aspects of a long term process which was operating on the Tasmanians, namely the effect of isolation. Perhaps the culture, remote for thousands of years from any outside stimulus, was becoming simplified and was losing some of its 'useful arts'. Perhaps in the very long run, measured in thousands of years, 3000 people were not enough to support and maintain a culture even of the simplicity of that practised during late Pleistocene Australia (Jones 1971:620).

In subsequent papers Jones (1976, 1977a) developed these ideas using the language of island biogeography. For "each species there was a minimum area and thus number of individuals below which long-term survival of a local population could not be maintained as man is also subject to these same forces" (Jones 1976:259). On islands this will be determined by rates of immigration and extinction, technology or ability to disperse across water, island distance and size. Jones' examination of the southern Australian islands led him to suggest that for the Tasmanians this critical threshold was reached at between $10-15 \mathrm{~km}$ and when island size was smaller than the annual territory of the social group or tribe (1977a:371); in the Tasmanian case $4000-5000 \mathrm{~km}^{2}$. In line with island biogeography studies, Jones recognised that this area would be reduced as one moved closer to tropical latitudes where biological productivity is higher and resources more evenly distributed both spatially and temporally.

Finally, numbers of people are directly equated with numbers of ideas and the decision by the Tasmanians to drop fish from the diet is seen as a maladaptation that "had the result of constricting their ecological universe" (Jones 1978:44):

...the world's longest isolation, the world's simplest technology. Were 4000 people enough to propel forever the cultural inheritance of Late Pleistocene Australia? Even if Abel Tasman had not sailed the winds of the Roaring Forties in 1642, were they in fact doomed [the Tasmanians] doomed to a slow strangulation of the mind (Jones 1977b:200).

The fact that these maladaptations could survive for so long unchecked was due, according to Jones, to lack of effective competition (another idea central to evolutionary ecology).

Without explicit reference to central place foraging or optimal foraging theory many coastal researchers have utilised these ideas in interpreting their data. For example, O'Connor (1982) interpreted the disproportionate representation of anatomical elements of large fauna such as seals as opposed to small to medium fauna at the Stockyard Site, Hunter Island, as due to processing of large fauna at or close to the procurement locale and proposed a model for island use based on the geographical location of sites and resources. Beaton (1985) noted the disparity between the large amount of shell flesh derived from reef flat species such as the large clams Tridacna sp. and Hippopus sp. and their poor representation in archaeological deposits and suggested that this might reflect shell processing on the reef or close to the live shell source, rather than dietary choice. In her study of Anbarra shell fish collecting, Meehan observed such behaviour in play in cases such as the large bivalve Batissa violacea (1982:73-4) where the shellfish is cooked and left at the gathering site and the meat returned to the base camp. All authors note that this behaviour will have obvious implications for assessing the dietary meat weight contributions of different species in archaeological deposits.

More recently Bird (1997) and Bird and Bleige-Bird (1997) have attempted to formalise such observations and speculations by the application, and testing, of a central place foraging model developed from the deductive methodology of behavioural ecology (itself a subset of evolutionary ecological theory) to generate predictions about human transport behaviour and explore the factors that influence variability in subsistence behaviour and the depositional consequences of such behaviour for the archaeological record. In essence their model predicts that the likelihood that shell will be deposited in a home base or central place will vary relative to processing costs and foraging range and "certain known parameters inherent to the resources (distribution and profitability)" (Bird and Bleige Bird 
1997:54). Their predictions were tested using ethnographic data derived from contemporary intertidal shellfish gathering strategies of the Meriam of the eastern Torres Strait Islands. Unlike most ecological approaches in Australian prehistory, theirs is placed firmly in a methodological framework, developed from an explicit body of theory. Their analysis demonstrates that as a

result of circumstances related to the costs and benefits of shellfish gathering, midden assemblage composition may vary independently of prey choice...among foragers interested in maximizing their rate of resource delivery to a central place, relatively high ranked shellfish resources (resources that on encounter have high energy yield per unit time processing; in the Meriam case, Hippopus and Tridacna spp.) are likely to be under-represented in residential deposits while low ranked shellfish (rocky shore resources) are likely to be over-represented in the diet. These relative differences will become more distinct in the archaeological record with increasing distances between the procurement location and central base (Bird and Bleige-Bird 1997:54).

Conversely the attributes of the resources will allow the researcher to predict the location of processing activities. Exceptions to this rule will occur in cases where the shell has some value independent of its shell/meat weight cost or travel distance, such as its use for tools or to keep flesh fresh over long periods of time. Bird (1997:291) states that the value of such models drawn from behavioural ecology is that they nominate "fitness related factors" that should influence behaviour in all circumstances and in predictable and explicitly testable ways. They therefore contend that in an evolutionary sense these models are directly applicable to prehistory (Bird and Bleige-Bird 1997:54).

\section{Review of palaeoecological methods}

What emerges from discussion of the arid zone and coastal examples presented above is that Australian archaeologists have long recognised the need to contextualise the archaeological record within environmental parameters. What may be less clear is that much recent ecologically based theorising is still frustrated by a similar lack of empirical data relating to late Quaternary palaeoenvironments to that which hindered our forbearers (e.g. Birdsell 1957; Gould 1973; Mulvaney and Golson 1971). Our understanding of palaeoenvironmental conditions is generally limited to sweeping, broad scale trends that do not adequately encompass or permit the expression of variability. The further back in time one looks, the less certain we are of exactly how such trends were expressed at the regional or local level and in turn what this may have translated to in terms of human ecology. Despite the ever-increasing sophistication of our ecologically based models, such as those relating to arid zone colonisation or explanations of shellfish species changes in coastal middens, our hypotheses are more theoretically than empirically based. We actually know very little about specific local environments and resource availability in the arid zone during the late Quaternary, or about individual marine biotic responses to transgressing and regressing shorelines. The apparent presence of lacustrine conditions in Lake Brachina in the Flinders Ranges between 20,500 and 16,000 BP during the height of glacial aridity (Cock et al. 1999) illustrates the dangers of adopting a pan-Australia environmental framework without fully investigating local responses to regional trends.

The last 30 years, and especially the last decade, of scientific inquiry have witnessed an expansion in techniques that improve our ability to extricate and interpret palaeoecological data, thereby allowing more opportunity to explore local conditions. In the following section we briefly outline some of these developments as applied in the Australian research context in an attempt to alert researchers to such investigative techniques, whose adoption in future studies may facilitate a more informed ecological archaeology in this country.

The analysis of pollen grains from non-archaeological depositionary contexts has long been the most commonly applied technique for investigating Quaternary vegetation change. The first such studies in the Australian context began to emerge in the 1970s, thus affording archaeologists their first glimpses of past vegetation patterns and hence plant resource availability (see Kershaw 1981:84-5 for a list of early palynological studies). Perhaps the most significant of these pollen records for archaeologists have been those from Lynch's Crater in northeastern Queensland (Kershaw 1974, 1975, 1976) and Lake George in central New South Wales (Singh et al. 1981a; Singh and Geisler 1985), offering vegetation histories in excess of 40,000 years with possible evidence of Aboriginal impact on the environment. Whilst in the past palynological studies have been conducted at relatively coarse temporal scales inappropriate for addressing questions of archaeological interest (Clark 1983a; Head 1989), the more recent emergence of fine-resolution pollen analysis offers a potential solution to this problem (Green and Dolman 1988).

The interpretation of pollen recovered from archaeological sites is a much more complicated issue, given the combination of natural and cultural processes of accumulation that may be involved (Dimbleby 1985). While there is some truth to the belief that Australian archaeological sites, particularly those located in the tropical and arid regions, are unsuited to pollen preservation, this is not always the case. The studies of Hope (1978) at Cave Bay Cave on Hunter Island, Tasmania, and Martin (1973) from three sites on the Nullabor Plain have been useful in assisting the reconstruction of local vegetation histories, and furthermore, the latter indicated the possibility of Aboriginal impact on that vegetation.

The examination of microscopic carbonised particles (charcoal) recovered from palaeoecological cores provides a direct line of information regarding burning events (Clark 1983a, 1983b; MacDonald et al. 1991; Patterson et al. 1987). Many of the same methodological difficulties that exist for pollen analysis also apply to charcoal studies, with some additional unique problems (Williams et al. 1998:201). These problems notwithstanding, carbonised particle counts are now routinely carried out in conjunction with palynological analyses. Increases in microscopic charcoal, in conjunction with vegetation change as attested to in the pollen record, are a lynchpin in arguments for evidence of Aboriginal impact on the Australian vegetation (e.g. Kershaw 1994; Kershaw et al. 1993; McKenzie and Kershaw 2000; Moss 1999; Moss and Kershaw 2000; Singh et al. 1981b; Van der Kaars 1990, 1991; Van der Kaars et al. 2000). The study of elemental carbon separated from other organics in palaeoecological cores via chemical means offers some solutions to the difficulties inherent in carbonised particle counts (Clark et al. 1997), however this approach is yet to be widely adopted in Australia.

Researchers have recognised for some time now that macroscopic charcoal might also be a potentially useful 
source of palaeovegetation information (e.g. Cubis 1980; Donaghue 1989; Hopkins et al. 1990). Such studies have now been undertaken in southwest Australia (Burke 1997; Dortch n.d.; Dortch and Burke 1997) and north Queensland (Hopkins et al. 1993, 1998) with great success. Perhaps of most relevance to this discussion are the studies of Smith et al. (1995, 1998) examining charcoal fragments from Puritjarra. These have provided a record of vegetation change in the area from ca. 27,000 BP to the recent past, viewed primarily as a response to climatic change. A late Holocene decline in Callitris glaucophylla is attributed possibly to the effects of Aboriginal burning (Smith et al. 1995:176), although Bowman (1998:395) suggests this explanation is "inconsistent with available ecological evidence".

Further advances in arid zone palaeovegetaion studies have also been made through the application of phytolith analysis. Phytoliths, being silica based plant fossils, are particularly resistant to decay and are consequently found in sediments of great antiquity across a variety of depositional environments (Bowdery 1989). Their identification is achieved through comparison with modern reference collections, although they do not offer the same level of taxonomic resolution as pollen analysis. Whilst these microfossils have long been perceived as a valuable source of palaeoecological data (Rovner 1971), their use in Australian studies has to date been limited, with a primary stumbling block being the absence of comparative phytolith collections.

Bowdery $(1996,1998)$ has examined phytoliths from Puritjarra in order to provide a further source of vegetation data for Central Australia, thereby complementing the charcoal record of Smith et al. (1995). Bowdery was able to further integrate the palaeovegetation and archaeological record, demonstrating that the first appearance of seed grinding material in the site was coincident with a shift to summer rainfall grasses in the area.

Detailed phytolith analyses are currently in progress at the archaeological site of Carpenter's Gap 1 in the southern Kimberley region of northwestern Australia (Wallis 1999). These studies are part of much wider multi-disciplinary studies at the site incorporating macrobotanic (McConnell 1997; McConnell and O'Connor 1997) and mineral skin investigations (Ward and Watchman 1999) designed to elucidate local environmental conditions during the period of the site's occupation.

Another recent development that holds promise for elucidating human-plant interactions is the analysis of starch grains recovered from archaeological contexts. Atchison and Fullagar (1998) recently reported a study of starch recovered from artefacts at the site of Jinmium in the east Kimberley. They suggest that further studies along these lines will potentially inform on "local vegetationfood processing and local subsistence" (1998:122). Of more direct relevance to this review, the identification of starch grains on grindstone material dating to the early Holocene from Puntutjarpa Rockshelter has contributed to the debate surrounding the timing and nature of systematic seed grinding in the arid zone (Garbin 1998; Veth et al. 1997).

Stable carbon, oxygen and nitrogen isotope analyses of various archaeological materials such as shells, phytoliths and human and animal bones and teeth also promise to provide new avenues for investigating such issues as dietary variability, seasonality of midden accumulation and palaeoecology, although they too are yet to become widely incorporated in Australian studies (e.g. Godfrey 1988; Pate 1994, 1995, 1997, 1998; Pate et al. 1998; Pate and Noble 2000; Roberts et al. 1999).

In the absence of conventional deposition sites (such as swamps) in the arid zone and northwestern Australia, researchers are investigating the potential of novel sedimentary sites as sources of palaeoecological data. In the semi-arid and arid zones of southern and central Australia stick-nest rat middens have proved to be valuable sources of fossil pollen, charcoal, phytoliths, starch and macrobotanical remains (Berry 1993; Head 1993; Head et al. 1998; McCarthy 1999; McCarthy et al. 1996; Pearson 1999; Pearson and Dodson 1993). While the use of such middens as sources of palaeoecological data is well established elsewhere, they are only beginning to be systematically investigated in Australia.

Similarly, in northwest Australia mud wasp nests have been recognised as valuable sources of pollen and phytoliths that can be used to provide "a detailed reconstruction of the palaeoenvironment for each interval of time represented by a nest" (Roberts et al. 1997:699). Systematic investigation of such nests are yet to be undertaken in Australia, although work has begun investigating a series of nests recovered from the Carpenter's Gap 1 rockshelter (Wallis, unpublished data).

The advances being made in the realm of palaeoecology notwithstanding, it is worth noting some of the inherent difficulties of working with proxy data. Whilst it is possible for ecologists to study complete functioning ecosystems, the palaeoecologist must deal with a biased, fragmentary and largely incomplete fossil record (Dodd and Stanton 1981; Harris and Thomas 1991). Although the events and behaviours archaeologists are interested in often occur in a time frame of days, seasons or years, the nature of the palaeoecological record and limitations of dating techniques precludes such highly detailed temporal resolution of the palaeoecological data (Clark 1983a; Frankel 1993; Head 1986, 1989, 1994, 1999; Little 1999):

Even within the most carefully researched localities there is almost no understanding of the environment on the time scale and at the level at which groups of prehistoric people reacted to it (White and O'Connell 1982:16).

Further complicating the situation are issues of spatial resolution and whether the available record is representative of regional or local patterns. Typically palaeoenvironmental data is regional in nature, whereas, if archaeologists hope to resolve human behaviours, we require knowledge of local conditions. Additionally, as noted, the effects of huntergatherer impact on the environment are likely to be subtle and difficult to disentangle from climatically induced change under any circumstances in the Australian palaeoecological record (Head 1994).

\section{Conclusions}

Despite the problems inherent in the use of palaeoecological data and modelling, the archaeological record cannot be profitably divorced from its environmental context. As Rowland (1999:12) notes:

Contrary to some current views, space is not just a raw material to be shaped by social process, and landscapes are not merely symbolic constructs. People in the past, as they do today, responded directly to environmental changes, but 
also indirectly to changes in landscape and resource distribution that were initiated by the changes.

As argued at the outset the apparent dichotomy between internalist and ecological explanation is somewhat spurious and arguably undesirable. Our ability to reconstruct even simple changes in the past is constrained by our lack of knowledge of past environments and bioproductivity. The challenge lies in directing future efforts towards more multidisciplinary research designed in the first instance to generate data of the temporal and spatial scales relevant for addressing specific archaeological questions.

\section{References}

Ambrose, S.H. and Lorenz, K.G. 1990 Social and ecological models of the Middle Stone Age in southern Africa. In P. Mellars (ed.) The Emergence of Modern Humans, pp. 3-33. Edinburgh: Edinburgh University Press.

Atchison, J. and Fullagar, R. 1998 Starch residues on pounding implements from Jinmium rockshelter. In R. Fullagar (ed.) A Closer Look: Recent Australian Studies of Stone Tools, pp. 109-25. Sydney: Archaeological Computing Laboratory, School of Archaeology, University of Sydney.

Barker, B.C. 1991 Nara Inlet 1: Coastal resource use and the Holocene marine transgression in the Whitsunday Islands, central Queensland. Archaeology in Oceania 26:102-9.

Beaton, J.M. 1985 Evidence for a coastal occupation time-lag at Princess Charlotte Bay (North Queensland) and implications for coastal colonisation and population growth theories for Aboriginal Australia. Archaeology in Oceania 20:1-20.

Berry, S.L. 1993 The potential of fossil mammal middens as indicators of vegetation history in central Australia. Australian Journal of Botany 39:305-13.

Bird, D.W. 1997 Behavioural ecology and the archaeological consequences of central place foraging among the Meriam. In C.M. Barton and G.A. Clarke (eds) Rediscovering Darwin: Evolutionary Theory and Archaeological Explanation, pp. 291-306. Archaeological Papers of the American Anthropological Association, No. 7.

Bird, D.W. and Bliege-Bird, R.L. 1997 Contemporary shellfish gathering strategies among the Meriam of the Torres Strait Islands, Australia: Testing predictions of a central place foraging model. Journal of Archaeological Science 24:3963.

Birdsell, J.B. 1957 Some population problems involving Pleistocene man. Cold Spring Harbor Symposia on Quantitative Biology 22:47-70.

Bowdery, D. 1989 Phytolith analysis: Introduction and applications. In W. Beck, A. Clarke and L. Head (eds) Plants in Australian Archaeology, pp. 161-96. St. Lucia: Anthropology Museum, University of Queensland. Tempus 1.

Bowdery, D. 1996 Phytolith Analysis Applied to Archaeological Sites in the Australian Arid Zone. Unpublished PhD thesis, Department of Archaeology and Anthropology, The Faculties, The Australian National University, Canberra.

Bowdery, D. 1998 Phytolith Analysis Applied to PleistoceneHolocene Archaeological Sites in the Australian Arid Zones. Hadrian Books.

Bowdler, S. 1979 Hunter Hill, Hunter Island. Unpublished PhD thesis, Department of Prehistory, Research School of Pacific Studies, The Australian National University, Canberra.

Bowdler, S. 1984 Hunter Hill, Hunter Island. Canberra: Department of Prehistory, Research School of Pacific Studies, The Australian National University. Terra Australis 8.
Bowman, D.M.J.S. 1998 Tansley Review No. 101: The impact of Aboriginal burning on the Australian biota. New Phytologist 140:385-410.

Brown, S. 1987 Toward a Prehistory of the Hamersley Plateau, Northwest Australia. Canberra: Department of Prehistory, Research School of Pacific Studies, The Australian National University. Occasional Papers in Prehistory 6.

Burke, S.F. 1997 Human Responses to Vegetation Change as Identified from Carbonised Plant Remains at Devil's Lair, South-west Western Australia. Unpublished BA(Hons) thesis, Centre for Archaeology, University of Western Australia, Perth.

Burney, D.A. 1997 Tropical islands as palaeoecological laboratories: Gauging the consequences of human arrival. Human Ecology 25(3):437-57.

Cane, S. 1984 Desert Camps: A Case Study of Stone Artefacts and Aboriginal Behaviour in the Western Desert. Unpublished PhD thesis, Department of Prehistory, Research School of Pacific Studies, The Australian National University, Canberra.

Clark, J.S., Cachier, H., Goldammer, J.G. and Stocks, B. (eds) 1997 Sediment Records of Biomass Burning and Global Change. Berlin: Springer.

Clark, R.L. 1983a Pollen and charcoal evidence for the effects of Aboriginal burning on the vegetation of Australia. Archaeology in Oceania 18(1):32-7.

Clark, R.L. 1983b Fire History from Fossil Charcoal in Lake and Swamp Sediments. Unpublished PhD thesis, Department of Biogeography and Geomorphology, Research School of Pacific Studies, The Australian National University, Canberra.

Cock, B.J., Williams, M.A.J. and Adamson, D.A. 1999 Pleistocene Lake Brachina: A preliminary stratigraphy and chronology of lacustrine sediments from the central Flinders Ranges, South Australia. Australian Journal of Earth Sciences 46:61-9.

Cubis, L. 1980 Hubble, bubble, boil and trouble? Dealing with plant remains in Australian archaeological sites. In I. Johnson (ed.) Holier Than Thou: Proceedings of the 1978 Kioloa Conference on Australian Prehistory, pp. 40. Canberra: Department of Prehistory, Research School of Pacific Studies, The Australian National University.

Diamond, J.M. 1972 Biogeographic kinetics: Estimation of relaxation times for avifaunas of southwest Pacific islands. Proceedings of the National Academy of Sciences, USA 69:3199-203.

Dimbleby, G.W. 1985 The Palynology of Archaeological Sites. London: Academic Press.

Dodd, J.R. and Stanton, R.J. 1981 Paleoecology, Concepts and Applications. New York: John Wiley and Sons.

Donaghue, D. 1989 Carbonised plant macrofossils. In W. Beck, A. Clark and L. Head (eds) Plants in Australian Archaeology, pp. 90-110. St. Lucia: Anthropology Museum, University of Queensland. Tempus 1.

Dortch, J. n.d. The environmental context of the Late Quaternary extinction of Petrogale in south-western Western Australia. Unpublished paper presented to the Conference on Australasian Vertebrate Evolution, Palaeotology and Systematics (CAVEPS), July 1997, Perth, Western Australia.

Dortch, J. and Burke, S. 1997 Identification of wood samples from submerged tree stumps in lower south-western Australia. Unpublished report submitted to the Anthropology Department, Western Australian Museum, Perth.

Edwards, D.A. and O'Connell, J.F. 1995 Broad spectrum diets in arid Australia. Antiquity 69:769-83. 
Frankel, D. 1993 Pleistocene chronological structures and explanations: A challenge. In M.A. Smith, M. Spriggs and B. Fankhauser (eds) Sahul in Review: The Archaeology of Australia, New Guinea and Island Melanesia, pp. 24-33. Canberra: Department of Prehistory, Research School of Pacific Studies, The Australian National University. Occasional Papers in Prehistory 24.

Friedman, J. 1979 Hegelian ecology: Between Rousseau and the world spirit. In P.C. Burnham and R.F. Ellen (eds) Social and Ecological Systems, pp. 253-70. London: Academic Press.

Garbin, G. 1998 Back to the grindstone: An analysis of the morphology and function of grinding implements from Puntutjarpa Rockshelter, Western Desert, Australia. Unpublished BA(Hons) thesis, Centre for Archaeology, University of Western Australia, Perth.

Godfrey, M.C.S. 1988 Oxygen isotope analysis: A means for determining the seasonal gathering of the pipi (Donax deltoides) by Aborigines in prehistoric Australia. Archaeology in Oceania 23(1):17-21.

Gould, R. A. 1967 Notes on the hunting, butchering, and sharing of game among the Ngatatjara and their neighbours in the West Australian desert. The Kroeber Anthropological Society Papers 36:41-66.

Gould, R.A. 1968 Preliminary report on excavations at Puntutjarpa rockshelter, near the Warburton Ranges, Western Australia. Archaeology and Physical Anthropology in Oceania 3:161-85.

Gould, R.A. 1969 Yiwara: Foragers of the Australian Desert. London: Collins.

Gould, R.A. 1971 The archaeologist as ethnographer: A case from the Western Desert of Australia. World Archaeology 3:143-77.

Gould, R.A. 1973 Australian archaeology in ecological and ethnographic perspective. Warner Modular Publications, Module 7:1-33.

Gould, R.A. 1974a The Australian Desert Culture. Paper presented at the annual meeting of the American Anthropological Association, Mexico City.

Gould, R.A. 1974b Some current problems in ethnoarchaeology. In C.B. Donnan and L.W. Clewlow, Jr. (eds) Ethnoarchaeology, pp. 29-48. Los Angeles: Institute of Archaeology, University of California.

Gould, R.A. 1977a Puntutjarpa Rockshelter and the Australian Desert Culture. Anthropological Papers of the American Museum of Natural History 54.

Gould, R.A. 1977b Ethno-archaeology, or, where do models come from? In R.V.S. Wright (ed.) Stone Tools as Cultural Markers: Change, Evolution and Complexity, pp. 162-8. Canberra: Australian Institute of Aboriginal Studies.

Gould, R.A. 1978a The anthropology of human residues. American Anthropologist 80:815-35.

Gould, R.A. 1978b Archaeological signatures of stress in the Australian desert. Paper presented at annual meeting of the American Anthropological Association, Los Angeles.

Gould, R.A. 1980 Living Archaeology. Cambridge: Cambridge University Press.

Gould, R.A. 1982 To have and not to have: The ecology of sharing among hunter gatherers. In N.M. Williams and E.S. Hunn (eds) Resource Managers: North American and Australian Hunter-Gatherers, pp. 69-91. AAAS Select Symposium 61 .

Gould. R.A. 1991 Arid-land foraging as seen from Australia: Adaptive models and behavioural realities. Oceania 62:12-33.

Gould, R.A. 1996 Faunal reduction at Puntutjarpa Rockshelter, Warburton Ranges, Western Australia. Archaeology in Oceania 31(2):72-86.

Green, D.G. and Dolman, G.S. 1988 Fine resolution pollen analysis. Journal of Biogeography 15:685-701.
Haberle, S. 1994 Anthropogenic indicators in pollen diagrams: Problems and prospects for late Quaternary palynology in New Guinea. In J. Hather (ed.) Tropical Archaeobotany: Applications and New Developments, pp. 172-201. London: Routledge.

Harris, D.R. and Thomas, K.D. (eds) 1991 Modelling Ecological Change: Perspectives from Neoecology, Palaeoecology and Environmental Archaeology. London: Institute of Archaeology, University College.

Hayden, B. 1976 Australian Western Desert Lithic Technology: An Ethno-archaeological Study of Variability in Material Culture. Unpublished PhD thesis, Department of Anthropology, University of Toronto.

Head, L. 1986 Palaeoecological contributions to Australian prehistory. Archaeology in Oceania 21(2):121-9.

Head, L. 1989 Prehistoric Aboriginal impacts on Australian vegetation: An assessment of the evidence. Australian Geographer 20(1):37-46.

Head, L. 1993 Stick-nest rat (Leporillus spp.) nests as sources of arid and semi-arid zone palaeoclimatic data: Review and prospects. Quaternary Australasia 11(1):38-42.

Head, L. 1994 Both ends of the candle? Discerning human impact on the vegetation. Australian Archaeology 39:82-6.

Head, L. 1999 Preface: Holocene impacts in Australia and the Western Pacific. Quaternary International 59:1-3.

Head, L., McCarthy, L., Quade, J., Witter, D., Allen, V. and Lawson, E. 1998 Classification and radiocarbon dating of Leporillus nests in semi-arid Australia and palaeoclimatic implications. Palaeoclimates 3(1-3):161-77.

Hiscock, P. 1988 Prehistoric Settlement Patterns and Artefact Manufacture at Lawn Hill, Northwest Queensland. Unpublished $\mathrm{PhD}$ thesis, University of Queensland, Brisbane.

Hiscock, P. 1994 Technological responses to risk in Holocene Australia. Journal of World Prehistory 8(3):267-92.

Hiscock, P. 1996 Mobility and technology in the Kakadu coastal wetlands. Indo-Pacific Prehistory Association Bulletin $15(2): 151-7$

Hiscock, P. 1999 Holocene coastal occupation of western Arnhem Land. In J. Hall and I. McNiven (eds) Australian Coastal Archaeology, pp. 91-103. Canberra: Archaeology and Natural History Publications, Research School of Pacific and Asian Studies, The Australian National University.

Hope, G.S. 1978 The late Pleistocene and Holocene vegetational history of Hunter Island, north western Tasmania. Australian Journal of Botany 26:493-514.

Hopkins, M.S., Graham, A.W., Hewett, R., Ash, J. and J. Head. 1990 Evidence of late Pleistocene fires and eucalypt forest from a north Queensland humid tropical rainforest site. Australian Journal of Ecology 15:345-7.

Hopkins, M.S., Ash, J., Graham, A.W., Head, J. and R.K. Hewett. 1993 Charcoal evidence of the spatial extent of the Eucalyptus woodland expansions and rainforest contractions in North Queensland during the late Pleistocene. Journal of Biogeography 20:357-72.

Hopkins, M.S., Graham, A.W., Head, J., Ash, J.E. and T. Armstrong 1998 Identification and radiocarbon dating of relict charcoal: Uses and constraints in palaeoecology. In G. Hope (ed.) Identifying Wood Charcoal Remains as Palaeo Evidence for Regions of Central and Northeast Australia, pp. 67-105. Canberra: Department of Archaeology and Natural History, Research School of Pacific and Asian Studies, The Australian National University.

Horton. D.R. 1981 Water and woodland: The peopling of Australia. Australian Institute of Aboriginal Studies Newsletter 16: 21-7.

Hughes. P.J. and R.J. Lampert 1980 Pleistocene occupation of the arid zone in southeast Australia: Research prospects for the Coopers Creek-Strzlecki Desert region. Australian Archaeologv 10:52-67. 
Hutchet, B.M.J. 1991 Theories and Australian prehistory: The last three decades. Australian Archaeology 33:44-51.

Jones, R. 1966 A speculative archaeological sequence for northwest Tasmania. Records of the Queen Victoria Museum 25:1-12.

Jones, R. 1968 The geographical background to the arrival of man in Australia and Tasmania. Archaeology and Physical Anthropology in Oceania 3:186-215.

Jones, R. 1971 Rocky Cape and the Problem of the Tasmanians. Unpublished PhD thesis, Department of Prehistory, Research School of Pacific Studies, The Australian National University, Canberra.

Jones, R. 1976 Tasmania: Aquatic machines and off-shore islands. In G. de G Sieveking, I.H. Longworth and K.E. Wilson (eds) Problems in Economic and Social Archaeology, pp. 235-63. London: Duckworth.

Jones, R. 1977a Man as an element of a continental fauna: The case of the sundering of the Bassian bridge. In J. Allen, $J$. Golson and R. Jones (eds) Sunda and Sahul: Prehistoric Studies in Southeast Asia, Melanesia and Australia, pp. 317. 86. London: Academic Press.

Jones, R. 1977b The Tasmanian paradox. In R.V.S. Wright (ed.) Stone Tools as Cultural Markers: Change, Evolution and Complexity, pp. 189-204. Canberra: Australian Institute of Aboriginal Studies.

Jones, R. 1978 Why did the Tasmanians stop eating fish? In R.A. Gould (ed.) Explorations in Ethno-Archaeology, pp 11-47. Albuquerque: University of New Mexico Press and Santa Fe: School of American Research.

Kendrick, G.W. and Morse, K. 1982 An Aboriginal shell midden deposit from Warrora coast, north-western Australia. Australian Archaeology 14:6-12.

Kershaw, A.P. 1974 A long continuous pollen sequence from north eastern Australia. Nature 251:222-3.

Kershaw, A.P. 1975 Late Quaternary vegetation and climate in northeastern Australia. Bulletin of the Royal Society of New Zealand 13:181-8

Kershaw, A.P. 1976 A late Pleistocene and Holocene pollen diagram from Lynch's Crater, northeastern Queensland, Australia. New Phytologist 77:469-98.

Kershaw, A.P. 1981 Quaternary vegetation and environments. In A. Keast (ed.) Ecological Biogeography of Australia, pp. 81101. The Hague: W. Junk.

Kershaw, A.P. 1994 Pleistocene vegetation of the humid tropics of northeastern Queensland, Australia. Palaeogeography, Palaeoclimatology, Palaeoecology 109:399-412.

Kershaw, A.P., MacKenzie, G.M. and McMinn, A. 1993 Quaternary vegetation history of northeastern Queensland from pollen analysis of ODP site 820. Proceedings of the Ocean Drilling Program, Scientific Results 133:107-14.

Kershaw, A.P., Moss, P.T. and Van der Kaars, S. 1997 Environmental change and the human occupation of Australia. Anthropologie 35(2-3):35-43.

Kirch, P.V. and Ellison, J. 1994 Palaeoenvironmental evidence for human colonisation of remote Oceanic islands. Antiquity 68:310-21.

Kirch, T.L. and P.V. Hunt (eds) 1997 Historical Ecology in the Pacific Islands: Prehistoric Environmental and Landscape Change. New Haven: Yale University Press.

Little, P.E. 1999 Environments and environmentalisms in anthropological research: Facing a new millenium. Annual Reviews in Anthropology 28:253-84.

Lourandos, H. 1997 Continent of Hunter-Gatherers: New Perspectives in Australian Prehistory. Cambridge: Cambridge University Press.

Lourandos, H. and Ross, A. 1994 The great 'intensification' debate: Its history and place in Australian archaeology. Australian Archaeology 39:54-63.
Mabbutt, J.A. 1977 Desert Landforms, Vol. 2. Canberra: Australian National University Press.

MacArthur, R.H. and Wilson, E.O. 1967 The Theory of Island Biogeography. Princeton: Princeton University Press.

MacDonald, G.M., Larsen, C.P.S., Szeicz, J.M. and Moser, K.A. 1991 The reconstruction of boreal forest fire history from lake sediments: A comparison of charcoal, pollen, sedimentological and geochemical indices. Quaternary Science Reviews 10:53-71.

Manne, T. 1999 Cultural Responses to Transgression on the Montebello Islands, Northwest Australia. Unpublished BA(Hons) thesis, Department of Archaeology, James Cook University, Townsville.

Martin, H.A. 1973 Palynology and historical ecology of some cave excavations in the Australian Nullarbor. Australian Journal of Botany 21:283-316.

McCarthy, L. 1999 A Holocene Vegetation History of the Flinders Ranges South Australia: Evidence from Leporillus spp. Stick-nest Rat Middens. Unpublished PhD thesis, School of Geosciences, University of Wollongong, Wollongong.

McCarthy, L., Head, L. and Quade, J. 1996 Holocene palaeoecology of the northern Flinders Ranges, South Australia, based on stick-nest rat Leporillus spp. middens: A preliminary overview. Palaeogeography, Palaeoclimatology, Palaeoecology 123:205-18.

McConnell, K. 1997 Palaeoethnobotanical Remains of Carpenter's Gap Site 1, The Kimberleys, Western Australia. Unpublished MA thesis, Division of Archaeology and Natural History, Research School of Pacific and Asian Studies, The Australian National University, Canberra.

McConnell, K. and O'Connor, S. 1997 40,000 year record of food plants in the southern Kimberley Ranges, Western Australia. Australian Archaeology 45:20-31.

McKenzie, G.M. and Kershaw, A.P. 2000 The last glacial cycle from Wyelangta the Otway region of Victoria, Australia. Palaeogeography, Palaeoclimatology, Palaeoecology 155:177-93.

Meehan, B.M. 1982 Shell Bed to Shell Midden. Canberra: Australian Institute of Aboriginal Studies.

Morse, K. 1993a West Side Story: Towards a prehistory of the Cape Range Peninsula, Western Australia. Unpublished PhD thesis, Centre for Archaeology, University of Western Australia, Perth.

Morse, K. 1993b New radiocarbon dates from North West Cape, Western Australia: A preliminary report. In M.A. Smith, M. Spriggs and B. Fankhauser (eds) Sahul in Review: Pleistocene Archaeology in Australia, New Guinea and Island Melanesia, pp. 155-63. Canberra: Department of Prehistory, Research School of Pacific and Asian Studies, The Australian National University. Occasional Papers in Prehistory 24.

Moss, P.T. 1999 Late Quaternary Environments of the Humid Tropics of Northeastern Australia. Unpublished $\mathrm{PhD}$ thesis, School of Geography and Environmental Science, Monash University, Melbourne.

Moss, P.T. and Kershaw, A.P. 2000 The last glacial cycle from the humid tropics of northeastern Australia: Comparison of a terrestrial and a marine record. Palaeogeography, Palaeoclimatology, Palaeoecology 155:155-76.

Mulvaney, D.J. and Golson, J. 1971 Aboriginal Man and Environment in Australia. Canberra: Australian Academy of Science.

O'Connell, J.F. 1977 Aspects of variation in central Australian lithic assemblages. In R.V.S. Wright (ed.) Stone Tools as Cultural Markers: Change, Evolution and Complexity. pp. 269-81. Canberra: Australian Institute of Aboriginal Studies. 
O'Connell, J.F. and Hawkes, K. 1981 Alyawara plant use and optimal foraging theory. In B. Winterhalder and E. Smith (eds) Hunter-Gatherer Foraging Strategies, pp. 99-125. Chicago: University of Chicago Press.

O'Connor, S. 1982 Bi-coastal: An interpretation of a Hunter Island midden. In S. Bowdler (ed.) Coastal Archaeology in Eastern Australia, pp. 133-41. Canberra: Department of Prehistory, Research School of Pacific Studies, The Australian National University.

O'Connor, S. 1999 30,000 Years of Aboriginal Occupation: Kimberley, North West Australia. Canberra: Department of Archaeology and Natural History and the Centre for Archaeological Research, Research School of Pacific and Asian Studies, The Australian National University. Terra Australis 14.

O'Connor, S. and Veth, P. 1993 Where the desert meets the sea: A preliminary report of the archaeology of the southern Kimberley coast. Australian Archaeology 37:25-34.

O'Connor, S. and Veth, P. 1996 A preliminary report on recent archaeological research in the semi-arid/arid belt of Western Australia. Australian Aboriginal Studies 2:42-50.

O'Connor, S., Veth, P. and Barham, A. 1999 Cultural versus natural explanations for lacunae in Aboriginal occupation deposits in northern Australia. Quaternary International 59: 61-70.

O'Connor, S., Veth, P. and Campbell, C. 1998 Serpent's Glen Rockshelter: Report of the first Pleistocene-aged occupation sequence from the Western Desert. Australian Archaeology 46:12-21.

O'Connor, S., Veth, P. and Hubbard, N. 1993 Changing interpretations of postglacial human subsistence and demography in Sahul. In M.A. Smith, M. Spriggs and B. Fankhauser (eds) Sahul in Review: The Archaeology of Australia, New Guinea and Island Melanesia, pp. 95-105. Canberra: Department of Prehistory, Research School of Pacific and Asian Studies, The Australian National University. Occasional Papers in Prehistory 24.

Pardoe, C. 1994 Bioscapes: The evolutionary landscape of Australia. Archaeology in Oceania 29(3):182-90.

Pate, F.D. 1986 The effects of drought on Ngatatjara plant use: An evaluation of optimal foraging theory. Human Ecology 14:95-115.

Pate, F.D. 1994 Bone chemistry and paleodiet. Journal of Archaeological Method and Theory 1:161-209.

Pate, F.D. 1995 Stable carbon isotope assessment of huntergatherer mobility in prehistoric South Australia. Journal of Archaeological Science 22:81-7.

Pate, F.D. 1997 Bone chemistry and paleodiet: Reconstructing prehistoric subsistence-settlement systems in Australia. Journal of Anthropological Archaeology 14:103-20.

Pate, F.D. 1998 Stable carbon and nitrogen isotope evidence for prehistoric hunter-gatherer diet in the lower Murray River basin, South Australia. Archaeology in Oceania 33:92-9.

Pate, F.D. and Noble, A.H. 2000 Geographic distribution of C3 and $\mathrm{C} 4$ grasses recorded in bone collagen stable carbon isotope values of South Australian herbivores. Australian Journal of Botany 48 (2):203-7.

Pate, F.D., Anson, T.J., Noble, A.H. and Schoeninger, M.J. 1998 Bone collagen stable carbon and nitrogen isotope variability in modern South Australian mammals: A baseline for palaeoecological inferences. Quaternary Australasia 16(1):43-51.

Patterson, W.A., Edwards, K.J. and Maguire, D.J. 1987 Microscopic charcoal as a fossil indicator of fire. Quaternary Science Reviews 6:3-23.

Pearson, S. 1999 Late Holocene biological records from the middens of stick-nest rats in the central Australian arid zone. Quaternary International 59:39-46.
Pearson, S. and Dodson, J.R. 1993 Stick-nest rat middens as sources of palaeoecological data in Australian deserts. Quaternary Research 39:347-54.

Pulsford, T. 1994 Montebello Repast: Early Holocene Environments and Economy on the Montebello Islands, Pilbara desert coast, Western Australia. Unpublished BA(Hons) thesis, Department of Archaeology, James Cook University, Townsville.

Roberts, A.L., Pate, F.D. and Hunter, R. 1999 Late Holocene climatic changes recorded in macropod bone collagen stable carbon and nitrogen isotopes at Fromm's Landing, South Australia. Australian Archaeology 49:48-49.

Roberts, R.G., Walsh, G., Murray, A., Olley, J.M., Jones, R., Morwood, M., Tuniz, C., Lawson, E., Macphail, M., Bowdery, D. and Naumann, I. 1997 Luminescence dating of rock art and past environments using mud-wasp nests in northern Australia. Nature 387:696-9.

Ross, A., Donnelly, T. and Wasson, R. 1992 The peopling of the arid zone: Human-environment interactions. In J. Dodson (ed.) The Naive Lands, pp. 76-114. Melbourne: Longman, Cheshire.

Rovner, I. 1971 Potential of opal phytoliths for use in palaeoecological reconstruction. Quaternary Research 1:343-59.

Rowland, M.J. 1983 Aborigines and environment in Holocene Australia: Changing paradigms. Australian Aboriginal Studies 2: 62-77.

Rowland, M.J. 1999 Holocene environmental variability: Have its impacts been underestimated in Australian pre history? The Artefact 22:11-40.

Schrire, C. 1982 The Alligator Rivers Prehistory and Ecology in Western Arnhem Land. Canberra: Department of Prehistory, Research School of Pacific Studies, The Australian National University. Terra Australis 7

Simberloff, D.S. and Wilson, E.O. 1970 Experimental zoogeography of islands: A two year record of colonisation. Ecology 51:934-7.

Singh, G. and Geissler, E.A. 1985 Late Cainozoic history of vegetation, fire, lake levels and climate at Lake George, New South Wales, Australia. Philosphical Transactions of the Royal Society of London B311:379-447.

Singh, G., Opdyke, N.D. and Bowler, J.M. 1981a Late Cainozoic stratigraphy, palaeomagnetic chronology and vegetational history from Lake George, New South Wales. Journal of the Geological Society of Australia 28:435-52.

Singh, G., Kershaw, A.P. and Clark, R.L. 1981b Quaternary vegetation and fire history. In A.M. Gill, R.H. Groves and I.R. Noble (eds) Australia: Fire and the Australian Biota, pp. 23-54. Canberra: Australian Academy of Science.

Smith, M.A. 1986 The antiquity of seed grinding in arid Australia. Archaeology in Oceania 21:29-39.

Smith, M.A. 1988 The Pattern and Timing of Prehistoric Settlement in Central Australia. Unpublished PhD thesis, University of New England, Armidale.

Smith, M. A. 1989 The case for a resident human population in the central Australian ranges during full glacial aridity. Archaeology in Oceania 24: 93-105.

Smith, M.A. 1996 Prehistory and human ecology in central Australia: An archaeological perspective. In S.R. Morton and D.J. Mulvaney (eds) Exploring Central Australia: Society, Environment and the 1894 Horn Expedition, pp. 6173. Chipping Norton: Surry Beatty and Sons.

Smith, M.A., Vellen, L. and Pask, J. 1995 Vegetation history from archaeological charcoals in central Australia: The late Quaternary record from Puritjarra rockshelter. Vegetation History and Archaeobotany 4: 171-7.

Smith, M.A., Vellen, L. and Pask, J. 1998 SEM photomicrographs of central Australian wood charcoals: A guide to the 
identification of archaeological and fossil charcoals. In G Hope (ed.) Identifying Wood Charcoal Remains as Palaeo Evidence for Regions of Central and Northeast Australia, pp. 5-63. Canberra: Archaeology and Natural History Publications, Research School of Pacific and Asian Studies, The Australian National University.

Smith, M.V. 1993 Recherche a l'Esperance: A Prehistory of the Esperance Region of South-Western Australia. Unpublished $\mathrm{PhD}$ thesis, Department of Anthropology, The University of Western Australia., Perth.

Thomas, N. 1981 Social theory, ecology and epistemology: Theoretical issues in Australian prehistory. Mankind 13(2):165-77

Thorley, P.B. 1998a Shifting Location, Shifting Scale: A Regional Landscape Approach to the Prehistoric Archaeology of the Palmer River Catchment, Central Australia. Unpublished $\mathrm{PhD}$ thesis, Northern Territory University, Darwin.

Thorley, P.B. 1998b Pleistocene settlement in the Australian arid zone: Occupation of an inland riverine landscape in the central Australian ranges. Antiquity 72:34-45.

Van der Kaars, S.A. 1990 Late Quaternary Vegetation and Climate of Australasia as Reflected by the Palynology of Eastern Indonesian Deep Sea Piston Cores. Unpublished $\mathrm{PhD}$ thesis, University of Amsterdam, Amsterdam.

Van der Kaars, S.A. 1991 Palynology of eastern Indonesian marine piston-cores: A late Quaternary vegetational and climatic record for Australasia. Palaeogeography, Palaeoclimatology, Palaeoecology 85:239-302.

Van der Kaars, S., Wang, X., Kershaw, A.P., Guichard, F. and Setiabudi, D.A. 2000 A late Quaternary palaeoecological record from the Banda Sea, Indonesia: Patterns of vegetation, climate and biomass burning in Indonesia and northern Australia. Palaeogeography, Palaeoclimatology, Palaeoecology 155:135-53.

Veth, P. 1989 Islands in the interior: A model for the colonization of Australia's arid zone. Archaeology in Oceania 24:81-92.

Veth, P. 1993a Islands in the Interior: The Dynamics of Prehistoric Adaptations within the Arid Zone of Australia. Ann Arbor, Michigan. International Monographs in Prehistory 3

Veth, P. 1993b The Aboriginal occupation of the Montebello Islands, northwest Australia. Australian Aboriginal Studies 2:39-47.
Veth, P. 1995 Aridity and settlement in north west Australia. Antiquity 69:733-46.

Veth, P. 1999 The occupation of arid coastlines during the terminal Pleistocene of Australia. In J. Hall and I.J. McNiven (eds) Australian Coastal Archaeology, pp. 65-72. Canberra: Archaeology and Natural History Publications, Research School of Pacific and Asian Studies, The Australian National University.

Veth, P. in press Origins of the Western Desert language: Convergence in linguistic and archaeological space and time models. Archaeology in Oceania.

Veth, P., Fullagar, R. and Gould, R. 1997 Residue and use-wear analysis of grinding implements from Puntutjarpa Rockshelter in the Western Desert: Current and proposed research. Australian Archaeology 44:23-5.

Wallis, L.A. 1999 Phytolith analysis at Carpenter's Gap 1 Changing patterns of human-plant interactions in the Kimberley over 40,000 years. Unpublished paper presented at the annual conference of the Australian Archaeological Association, December 1999, Perth, Western Australia.

Ward, I. and Watchman, A. 1999 The environmental and archaeological implications of finely laminated rockshelter crusts, southern Kimberley, Western Australia. Unpublished paper presented at the annual conference of the Australian Archaeological Association, December 1999, Perth, Western Australia

Wenke, R.J. 1981 Explaining the evolution of cultural complexity: A review. In M.B. Schiffer (ed.) Advances in Archaeological Method and Theory, pp. 79-129. New York Academic Press.

White, J.P. and O'Connell, J.F. 1982 A Prehistory of Australia New Guine and Sahul. Sydney: Academic Press.

Whitley, D.S. 1998 New approaches to old problems: Archaeology in search of an ever elusive past. In D.S Whitley (ed.) Reader in Archaeological Theory: Postprocessual and Cognitive Approaches, pp. 1-28. London: Routledge.

Williams, M., Dunkerley, D., De Deckker, P., Kershaw, A.P. and Chappell, J. 1998 Quaternary Environments, 2nd edn. London: Arnold Publishers.

Winterhalder, E. and Smith, E.A. (eds) 1981 Hunter-Gatherer Foraging Strategies: Ethnographic and Archaeological Analyses. Chicago: University of Chicago Press.

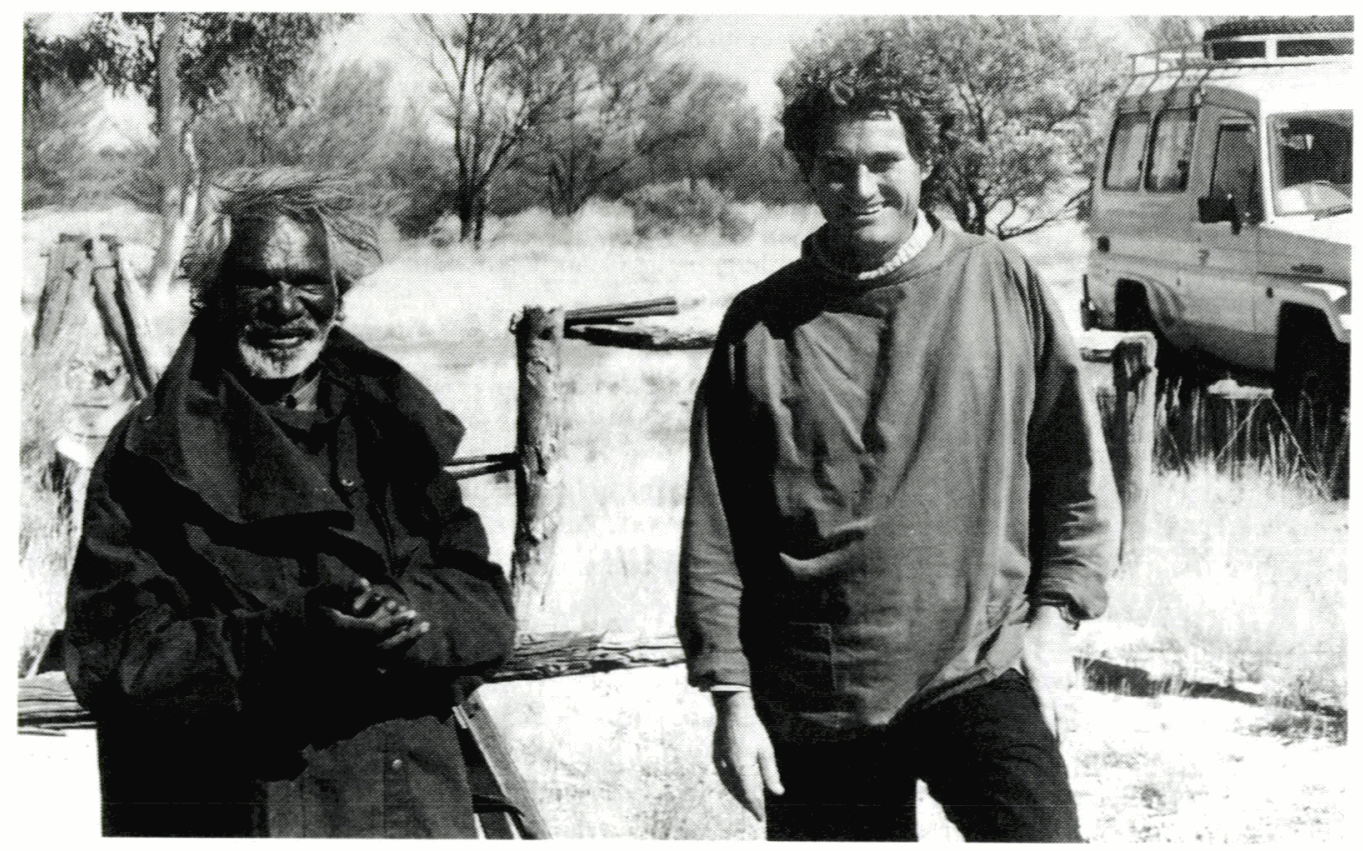

Mack Gardner and Peter Veth during site recording program Central Canning Stock Route. July 1996. Photo: courtesy of P. Veth 